\title{
MICROSTRUCTURAL AND MECHANICAL CHARACTERIZATION OF ELECTRON BEAM WELDED JOINTS OF HIGH STRENGTH S960QL AND WELDOX 1300 STEEL GRADES
}

\begin{abstract}
The paper shows the results of metallographic examination and mechanical properties of electron beam welded joints of quenched and tempered S960QL and Weldox 1300 steel grades. The aim of this study was to examine the feasibility of producing good quality electron beam welded joints without filler material.

Metallographic examination revealed that the concentrated electron beam significantly affects the changes of microstructure in the weld and the adjacent heat affected zone (HAZ) in both steel grades. The microstructure of the welded joints is not homogeneous. The four zones, depending on the distance from the weld face, can be distinguished. Basically, the microstructure of the weld consists of a mixture of martensite and bainite. However, the microstructure of HAZ depends on the distance from the fusion line. It is composed of martensite near the fusion line and a mixture of bainite and ferrite in the vicinity of the base material.

Significant differences in mechanical properties of the welded joints were observed. For a butt welded joint of the S960QL steel grade the strength is at the level of the strength of the base material $\left(\mathrm{R}_{\mathrm{m}}=1074 \mathrm{MPa}\right)$. During the bending test the required angle of $180^{\circ}$ was achieved. The impact strength at $-40^{\circ} \mathrm{C}$ was $71,7 \mathrm{~J} / \mathrm{cm}^{2}$. In the case of the Weldox 1300 steel grade butt welded joints exhibit high mechanical properties $\left(\mathrm{R}_{\mathrm{m}}=1470 \mathrm{MPa}\right)$, however, the plastic properties are on the lower level than for the base material.

Keywords: electron beam welding, high strength quenched and tempered steel, weld microstructure
\end{abstract}

\section{Introduction}

In recent years, numerous steel manufacturers have increased their interest in ultra-high strength quenched and tempered steels that simultaneously exhibit low brittle-toductile transition temperature (BDTT). This is associated with the evolution of more complex steel structures that, in turn, enforces additional requirements on the steel properties. Since the dimensions of industrial structures continously increase, the designers of these structures as well as steel manufacturers work on their weight and cost reduction. These apparently conflicting requirements can be met by the low alloyed steels with higher mechanical properties. The low BDTT is provided by toughened fine-grained steels. On the other hand, the high mechanical properties (yield strength up to $1300 \mathrm{MPa}$ ) can be achieved by selecting a suitable chemical composition as well as the appropriate conditions of rolling and heat treatment [1].

Nowadays, ultra-high strength low alloy steel is widely used in engineering constructions. The principal advantage of these steels is a good combination of strength and toughness, higher strength/weight ratio, formability and also good weldability. Therefore, the ultra-high strength steels are used primarily in the construction of cranes, heavy duty trucks, mobile cranes and other highly loaded components [2]. They are also useful in the automotive industry [3-9].

These steels, as materials for constructions, are relatively new. A wider application of them would require changes in construction design, development of new forming technologies and most importantly improvements in welding technology. That is why, the investigation of weldability is of primary importance. The weldability tests are the basis for the development of new welding technologies. Also, a deeper understanding of phenomena occurring during welding that influence the microstructure, and thus mechanical properties of welded elements, becomes an important issue in the broader application of these steels [10].

The previous studies on welding of quenched and tempered steel were aimed at the determination of the mechanical properties and microstructure of welds produced by arc welding methods. It was found that the optimum cooling time $t_{8 / 5}$ (the highest mechanical properties) during the MAG welding of the S960QL steel grade is between 6 and $10 \mathrm{~s}$ for the heat input of 500-700 $\mathrm{J} / \mathrm{mm}$ [11]. However, according to the authors best knowledge, traditional welding methods are not appriopriate for high and ultra- high strength steels. Some researchers investigated a laser beam welded high strength steel [12]. A relation between

\footnotetext{
TESTING OF MATERIALS WELDABILITY AND WELDED CONSTRUCTION DEPARTMENT, INSTYTUT SPAWALNICTWA (INSTITUTE OF WELDING), 16-18 BŁOGOSŁAWIONEGO CZESŁAWA STR., 44-100 GLIWICE, POLAND

** AGH UNIVERSITY OF SCIENCE AND TECHNOLOGY, FACULTY OF METAL ENGINEERING AND INDUSTRIAL COMPUTER SCIENCE, AL. MICKIEWICZA 30, 30-059 KRAKOW, POLAND

\# Corresponding author: sylwester.blacha@is.gliwice.pl
} 
a chemical composition, weld microstructure and mechanical properties were thoroughly examined. These studies showed that plastic properties of the welded steel strongly depend on the carbon content, in particular, it was shown that the highest strength of the welded steel corresponded to a low carbon content and bainitic microstructure. The other promising welding technology that can be applied for high and ultra- high strength steels is the electron beam welding process [13].

So far, the studies on electron beam welding on steel with a yield strength approaching $1300 \mathrm{MPa}$ have not been carried out. However, electron beam welding was used to join 2N11K13H3M and N19M4T maraging steels [14] and 300M-type steel used in the aerospace industry [15]. The studies of $300 \mathrm{M}$ steel welded joints showed that the microstructure of the weld is composed of bainite, ferrite and primary austenite, whereas the heat affected zone is composed of ferrite and cementite. The strength of welded joints after tempering was $1900 \mathrm{MPa}$ [15]. In the case of the $2 \mathrm{~N} 11 \mathrm{~K} 13 \mathrm{H} 3 \mathrm{M}$ and N19M4T steels it was found that after an additional heat treatment of welded joints the microstructure of weld was uniform. The strength of these welded joints approached $1400 \mathrm{MPa}$.

A significant difference between the microstructure of the arc welded and electron beam welded joints was demonstrated in Ref. [16] where steel grades 20KhGSN2MFA and 20HGSN2MFA-VD $\left(\mathrm{R}_{\mathrm{m}}=1350 \mathrm{MPa}, \mathrm{R}_{\mathrm{e}}=1200 \mathrm{MPa}\right)$ were investigated. The studies revealed that the microstructure of the joint produced by electron beam consisted of smaller grains $(120 \mu \mathrm{m})$, while the arc welded joints were characterized by an average grain size of $200 \mu \mathrm{m}$. The significant influence of the energy of electron beam on the microstructure, impact strength and the width of the weld face was demonstrated in Ref. [17]. The tests carried out on unalloyed steel shown indicated that a noticeable decrease in BDTT was induced by increasing of welding speed. The reason for such behaviour resulted from changes in the microstructure effect can be overcome by preheating elements to $200^{\circ} \mathrm{C}$ that significantly reduces the thermal gradient.

The present study addresses the effect of technological parameters of electron beam welding on microstructure and mechanical properties of two quenched and tempered grades of high strength low alloy steel welded joints (S960Q and Weldox 1300). The main goal of the present investigation was to determine and compare microstructure and mechanical properties of electron beam welded joints of these steel grades. In particular, the microstructural investigation, microhardness measurements, tensile, impact toughness and bend tests were carried out to compare the joint performance of both steels.

\section{Experimental procedure}

\section{Base metal}

The investigation was carried out on S960QL and Weldox 1300 steel grades welded joints. The thickness of the welded plates was 11 and $6 \mathrm{~mm}$ for the S960QL and Weldox 1300 steels, respectively. The nominal mechanical properties and chemical composition of both steels are given in Tables 1 and 2 .

TABLE 1

Mechanical properties of investigated steels

\begin{tabular}{|c|c|c|c|c|c|c|}
\hline & \multirow{2}{*}{$\begin{array}{c}\mathbf{R}_{\mathbf{e}} \\
\mathbf{M P a}\end{array}$} & \multirow{2}{*}{$\begin{array}{c}\mathbf{R}_{\mathrm{m}} \\
\mathbf{M P a}\end{array}$} & \multirow{2}{*}{$\begin{array}{l}A_{5} \\
\%\end{array}$} & \multicolumn{3}{|c|}{ Impact energy $^{3}, \mathbf{J}$} \\
\hline & & & & $\mathrm{0}^{\circ} \mathrm{C}$ & $-20^{\circ} \mathrm{C}$ & $-40^{\circ} \mathrm{C}$ \\
\hline $\mathrm{S} 960 \mathrm{QL}^{1}$ & Min 960 & $980-1150$ & Min 10 & 40 & 35 & 30 \\
\hline $\begin{array}{l}\text { Weldox } \\
1300^{2}\end{array}$ & Min 1300 & $1400-1700$ & Min 8 & - & - & 2 \\
\hline
\end{tabular}

${ }^{1}$ The mechanical properties acc. to the PN-EN 10025-6 standard [21]

${ }^{2}$ The mechanical properties declared by the manufacturer

${ }^{3}$ Minimum values of impact energy for impact tests on V-notch test pieces

TABLE 2

Chemical composition of investigated steel

\begin{tabular}{|c|c|c|c|c|c|c|c|c|c|c|c|c|c|c|}
\hline \multirow{2}{*}{ Steel grade } & \multicolumn{14}{|c|}{ Chemical composition [\%] wt. } \\
\hline & C & Si & Mn & B & $\mathbf{N b}$ & $\mathrm{Cr}$ & $\mathbf{V}$ & $\mathbf{C u}$ & $\mathbf{T i}$ & Mo & $\mathrm{Ni}$ & $\mathbf{N}$ & $\mathbf{P}$ & $\mathbf{S}$ \\
\hline $\mathrm{S} 60 \mathrm{QL}^{1}$ & 0.22 & 0.86 & 1.80 & 0.006 & 0.07 & 1.60 & 0.14 & 0.55 & 0.07 & 0.74 & 2.10 & 0.016 & 0.025 & 0.012 \\
\hline Weldox $1300^{2}$ & 0,21 & 0,21 & 0,85 & 0,001 & 0,015 & 0,47 & - & 0,02 & 0,003 & 0,39 & 1,26 & - & - & - \\
\hline
\end{tabular}

that resulted from a different amount of heat introduced into the welded joint. The experiments on welding S960QL, S1100QL and $\mathrm{S} 1300 \mathrm{QL}$ steel using electron beam at atmospheric pressure showed that welding with a filler material allows for producing defect-free joints, however, during tensile testing the sample ruptured in the HAZ $[18,19]$. Despite this issue, the technological conditions were elaborated for welding S690QL and S960QL steel elements, intended for applications in wind towers, using an electron beam at atmospheric pressure [20]. It was described in this study that during the welding of elements with a thickness of $30 \mathrm{~mm}$, a problem of hot cracking can appear. This adverse

\section{Welding procedure}

The welded joints, in a butt configuration, were produced at the Institute of Welding, Gliwice, Poland using an electron beam welding machine (Cambridge Vacuum Engineering Ltd, United Kingdom) with $150 \mathrm{kV}$ accelerating voltage capacity. Several trial runs were carried out to find the welding parameters that produce a full penetration bead in a single pass. In order to avoid joint distortions during welding, the plates were rigidly clamped in a holder. Electron beam welding was conducted 
at a constant welding speed of $800 \mathrm{~mm} / \mathrm{min}$. The accelerating valtage was set to $120 \mathrm{kV}$ and a beam current in the range of 29 to $33 \mathrm{~mA}$. Five trial runs were carried out for the S960QL steel. For welding of the Weldox 1300 steel a beam current of $20 \mathrm{~mA}$ was selected. The welding was performed without any filler material and without preheating. The detailed process parameters are collected in Table 3.

TABLE 3

EBW process parameters

\begin{tabular}{|l|c|c|c|c|c|c|}
\hline \multirow{3}{*}{ Parameter } & \multicolumn{5}{|c|}{ S960QL } & $\begin{array}{c}\text { Weldox } \\
\mathbf{1 3 0 0}\end{array}$ \\
\cline { 2 - 6 } & \multicolumn{5}{|c|}{ Number of sample } \\
\cline { 2 - 6 } & $\mathbf{1}$ & $\mathbf{3}$ & $\mathbf{4}$ & $\mathbf{5}$ & $\mathbf{6}$ \\
\hline $\begin{array}{l}\text { Accelerating voltage } \\
(\mathrm{kV})\end{array}$ & \multicolumn{5}{|c|}{120} & 120 \\
\hline Beam current (mA) & 29,0 & 30,0 & 31,0 & 32,0 & 33,0 & 20 \\
\hline Beam Focus (mA) & \multicolumn{5}{|c|}{700 (surface) } & $\begin{array}{c}670 \\
\text { (surface) }\end{array}$ \\
\hline Working distance (mm) & \multicolumn{5}{|c|}{$304 \mathrm{~mm}$} & $304 \mathrm{~mm}$ \\
\hline Welding speed (mm/min) & \multicolumn{5}{|c|}{800} & 800 \\
\hline Vacuum chamber (bar) & \multicolumn{5}{|c|}{$10^{-4}$} \\
\hline
\end{tabular}

\section{Testing}

Mechanical properties of welded joints (tensile strength TS) were determined at $+20^{\circ} \mathrm{C}$. The tests were performed using an Instron 4210 tensile test machine. The impact test were carried out at temperatures of $0,-20$ and $-40^{\circ} \mathrm{C}$. The V notched Charpytype specimens were used, in accordance with the PN-EN ISO 148-1:2010 [22] and PN-EN ISO 9016:2013-05 [23] standards.

The Vickers microhardness (HV 0.05) and Vickers hardness (HV10) measurements across the HAZ and base metal were carried out on the metallographic samples. The scheme of hardness measurements is presented in Figure 1. All measurements were performed on an automatic KB50 FA (Prüftechnik GmgH) hardness tester in accordance with the PN-EN ISO 9015-1:2011 [24] and PN-EN ISO 6507-1:2007 [25] standards.

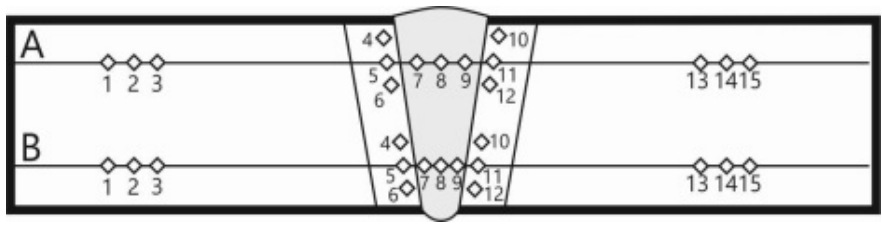

Fig. 1. Scheme of hardness measurements HV10

Microstructural examinations of steels and welded joints were carried out according to the PN-EN ISO 17639:2013-12E [26] standard on a light microscope Eclipse MA 200 (Nikon). In order to reveal microstructure the welded cross-sections were mechanically ground, polished and chemically etched with Nital regent ( $2 \%$ nitric acid).

\section{Results and discussion}

The low magnification macrostructures of the electron beam welding (EBW) butt welded joints of the steel S960QL produced at different beam currents are shown in Figure 2. The near full penetration was achieved for the $33.0 \mathrm{~mA}$ beam current. It was, therefore, assumed that the full penetration would be obtained if the beam current was increased to $34 \mathrm{~mA}$. In the as-received condition (after quenching and tempering) the microstructure of the S960QL steel was composed of tempered martensite.

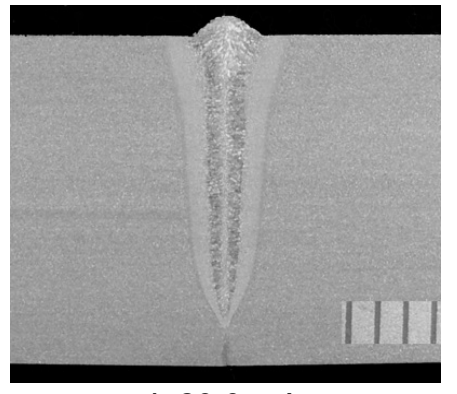

$\mathrm{I}=29.0 \mathrm{~mA}$

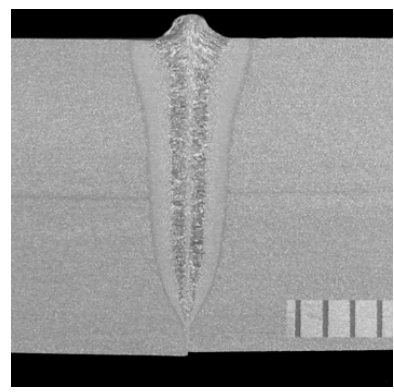

$\mathrm{I}=31.0 \mathrm{~mA}$

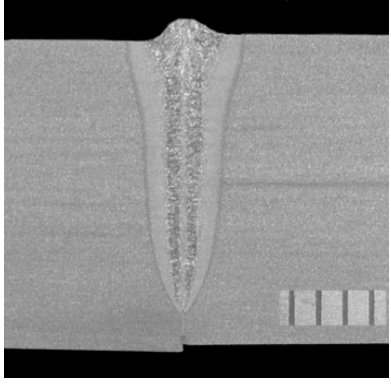

$\mathrm{I}=30.0 \mathrm{~mA}$

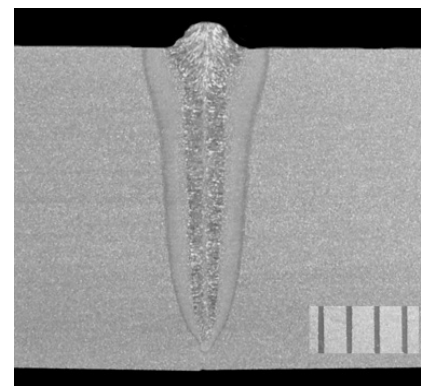

$\mathrm{I}=32.0 \mathrm{~mA}$

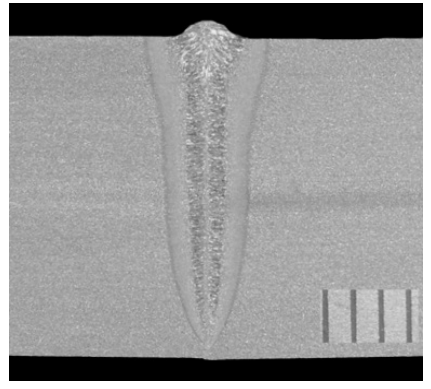

$\mathrm{I}=33.0 \mathrm{~mA}$

Fig. 2. The macrostructure of the butt welded joints of the S960QL steel grade for different beam currents

The macrostructure of the final weldment is shown in Figure 3. The microstructure of the weld and its vicinity (HAZ) is not uniform. It is mainly composed of bainite and martensite. Several microstructural zones, at different distances from the weld axis, can be distinguished. The microstructures of the particular weld zones at higher magnifications are presented in Table 4. The changes in microhardness across the particular zones are shown in Figure 4. Nearby the fusion line (short cooling times $\mathrm{t}_{8 / 5}$ ) the hardness is reduced; for a greater distance from the fusion the hardness was higher. This effect occurs for a high heating rate. 
630

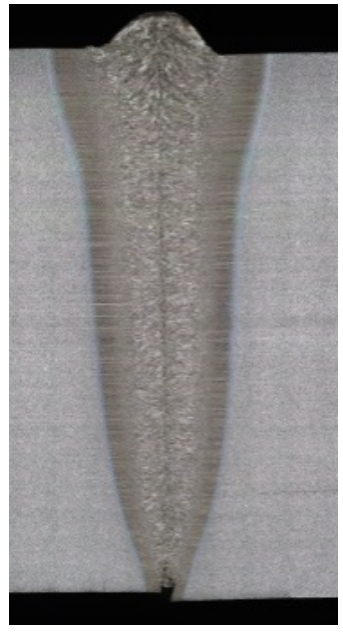

Fig. 3. Macrostructure of electron beam welded joints produced in one run at $34.0 \mathrm{~mA}$

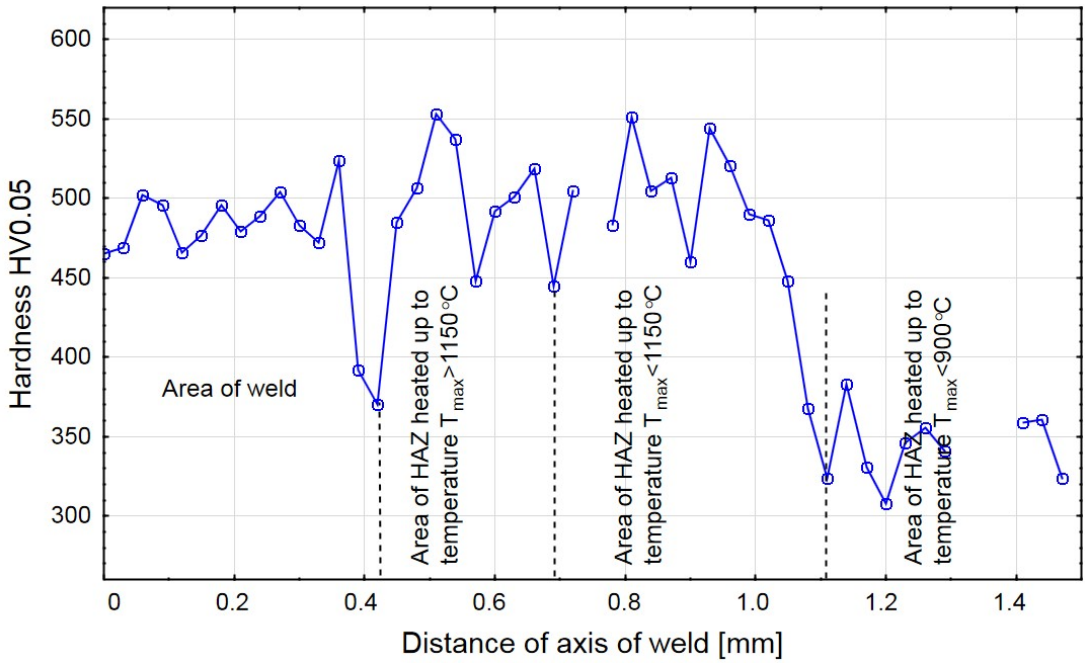

Fig. 4. The hardness distribution in the electron beam welded joint of steel S960QL

TABLE 4

The microstructures of the individual regions of the electron beam welded joint, S690QL steel

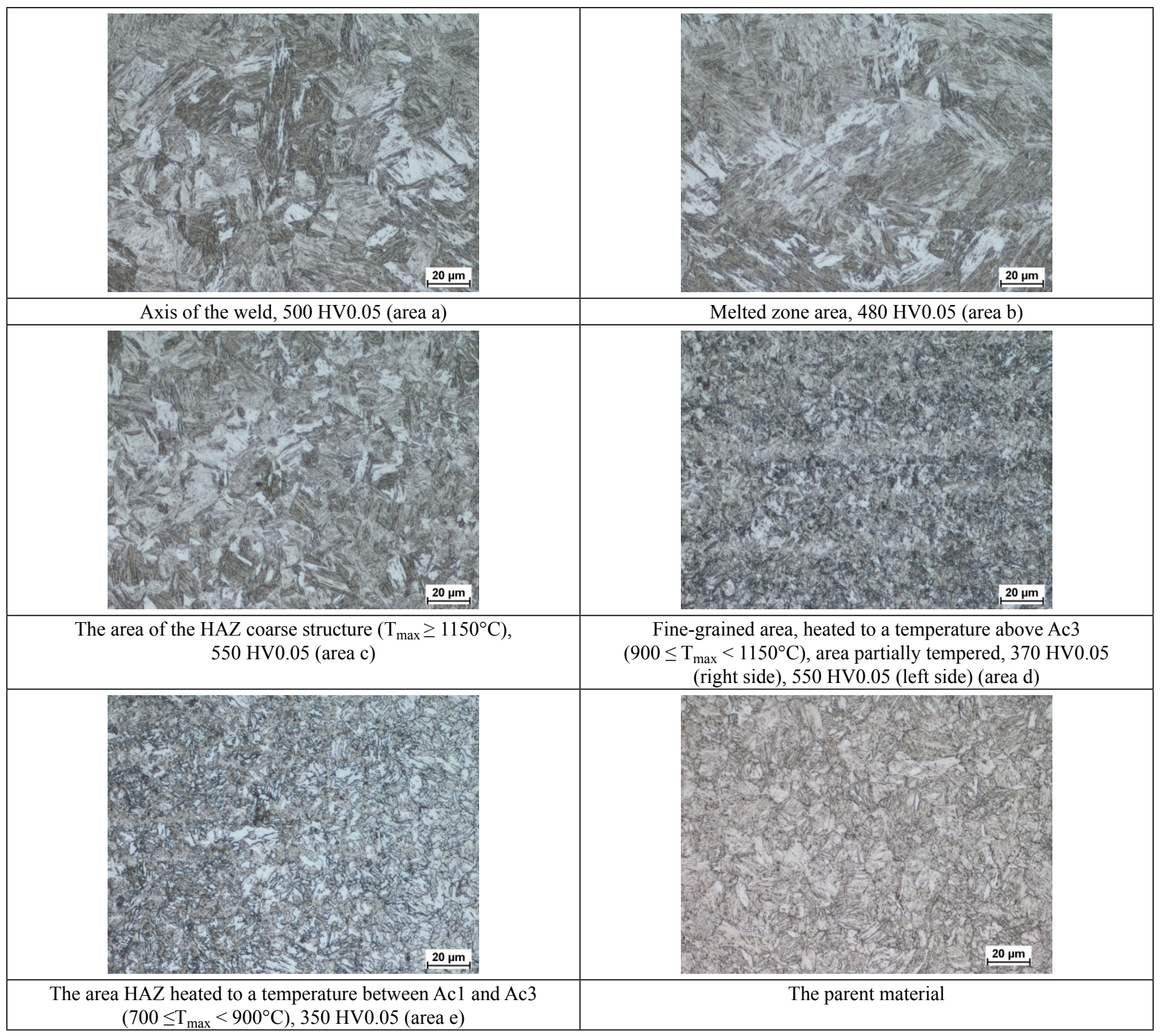


When applying a concentrated electron beam the heating rate is about $6000 \mathrm{~K} / \mathrm{s}$, and the cooling rate of HAZ is less than $2 \mathrm{~s}\left(\right.$ time $\left.\mathrm{t}_{8 / 5}\right)$. For comparison, the heating rate for arc welding processes is much lower about $200 \mathrm{~K} / \mathrm{s}$, and the cooling time of $t_{8 / 5}$ amount of dozen or so seconds [28]. The different thermal conditions that occur during the process of electron beam welding cause that the hardness of the HAZ is less near the weld line (short cooling time $t_{8 / 5}$ ) the hardness is reduced to a value of $370 \mathrm{HV}$ from $485 \mathrm{HV}$ for $\mathrm{S} 960$ steel. Such a phenomenon is not observed in the arc welded joints where the heating rate is much lower. Therefore, it is believed that at very rapid thermal cycles the level of austenite homogenization is small and the growth of austenite grains is suppressed. Unfortunately, there is no possibility of practical verification of this assessment for the EBW conditions. There is lack of methods of physical simulation of the EB proces. However, it is apparent that these fast thermal cycles have a significant impact on the microstructure and properties of the welded joint. Thus, the temperature ranges presented in Fig. 4 have only information function.

The results of mechanical properties of the EBW joint of the steel S960QL grade are collected in Table 5. The tensile strength is at the level of the strength of the base material, TS $=1074 \mathrm{MPa}$. The required bending angle of $180^{\circ}$ was achieved. The impact strength at $-40^{\circ} \mathrm{C}$ was $71,7 \mathrm{~J} / \mathrm{cm}^{2}$.

The results of supplemental hardness measurements (HV10) performed in places marked in Fig. 1 are presented in Table 6. The hardness values were lower than 450 HV10 - the tolerable hardness level for qualifying welding technology according to the ISO 15614-11 specifications [27].

The microstructure of the Weldox 1300 steel was composed of tempered martensite (Fig. 5). The macrostructure of the EBW joint of $6 \mathrm{~mm}$ in thickness is shown in Figure 6. The results of hardness measurements are shown in Figure 7.

TABLE 5

The mechanical properties of the EBW joint, S960QL steel

\begin{tabular}{|c|c|c|c|c|c|}
\hline \multirow{2}{*}{ No. } & \multirow{2}{*}{ Sample designation } & \multicolumn{2}{|c|}{ Strength properties } & \multirow{2}{*}{$\begin{array}{c}\text { Bend angle } \\
{\left[^{\circ}\right]} \\
\end{array}$} & \multirow{2}{*}{ Remarks } \\
\hline & & $\mathrm{F}_{\mathrm{m}},[\mathrm{kN}]$ & $\mathbf{R}_{\mathrm{m}}$, [MPa] & & \\
\hline 1 & R1 & 284,1 & 1078 & - & rupture out of weld \\
\hline 2 & R2 & 280,3 & 1074 & - & rupture out of weld \\
\hline 3 & R3 & 286,1 & 1070 & - & rupture out of weld \\
\hline 4 & FBB1 & - & - & $180^{1}$ & without cracks \\
\hline 5 & FBB2 & - & - & $180^{1}$ & without cracks \\
\hline 6 & RBB1 & - & - & $180^{1}$ & without cracks \\
\hline \multirow[t]{4}{*}{7} & RBB2 & - & - & $180^{1}$ & without cracks \\
\hline & & \multicolumn{3}{|c|}{ Impact energy $[\mathrm{J}] /$ toughness $\left[\mathrm{J} / \mathrm{cm}^{2}\right]$} & \\
\hline & & \multicolumn{3}{|c|}{ Temperature } & \\
\hline & & $0^{\circ} \mathrm{C}$ & $-20^{\circ} \mathrm{C}$ & $-40^{\circ} \mathrm{C}$ & \\
\hline 8 & $\mathrm{KV} / \mathrm{VW}$ & $94 / 117,5$ & $40 / 50,0$ & $40 / 50,0$ & \\
\hline 9 & KV/VW & $162 / 202,5$ & $170 / 212,5$ & $58 / 72,5$ & \\
\hline 10 & KV/VW & - & $52 / 65,0$ & $74 / 92,5$ & \\
\hline
\end{tabular}

TABLE 6

Results of hardness tests for electron beam welded joints, HV10, S960QL steel

\begin{tabular}{|c|c|c|c|c|c|c|c|c|c|c|c|c|c|c|c|}
\hline & 1 & 2 & 3 & 4 & 5 & 6 & 7 & 8 & 9 & 10 & 11 & 12 & 13 & 14 & 15 \\
\hline Line A & 346 & 345 & 344 & 434 & 441 & 447 & 440 & 426 & 434 & 436 & 438 & 445 & 344 & 343 & 343 \\
\hline Line B & 343 & 340 & 344 & 432 & 455 & 466 & 434 & 429 & 436 & 465 & 452 & 470 & 342 & 342 & 342 \\
\hline
\end{tabular}

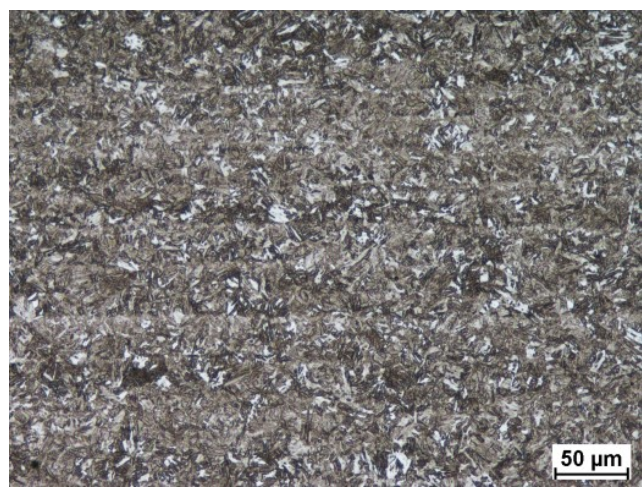

Fig. 5. The microstructure of Weldox 1300 steel in the as-received condition, 513 HV10

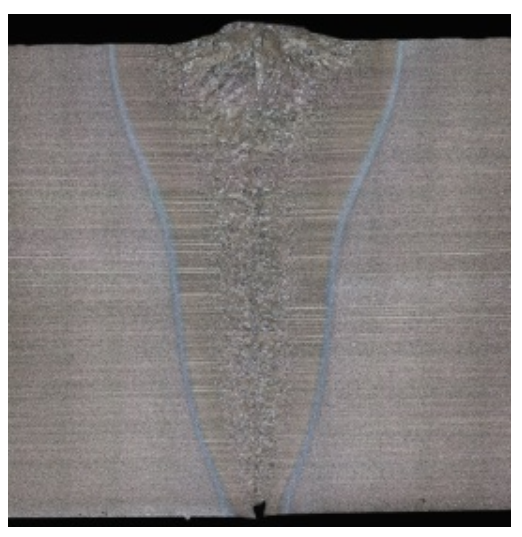

Fig. 6. Macrostructure of the Weldox 1300 steel EBW joint 
632

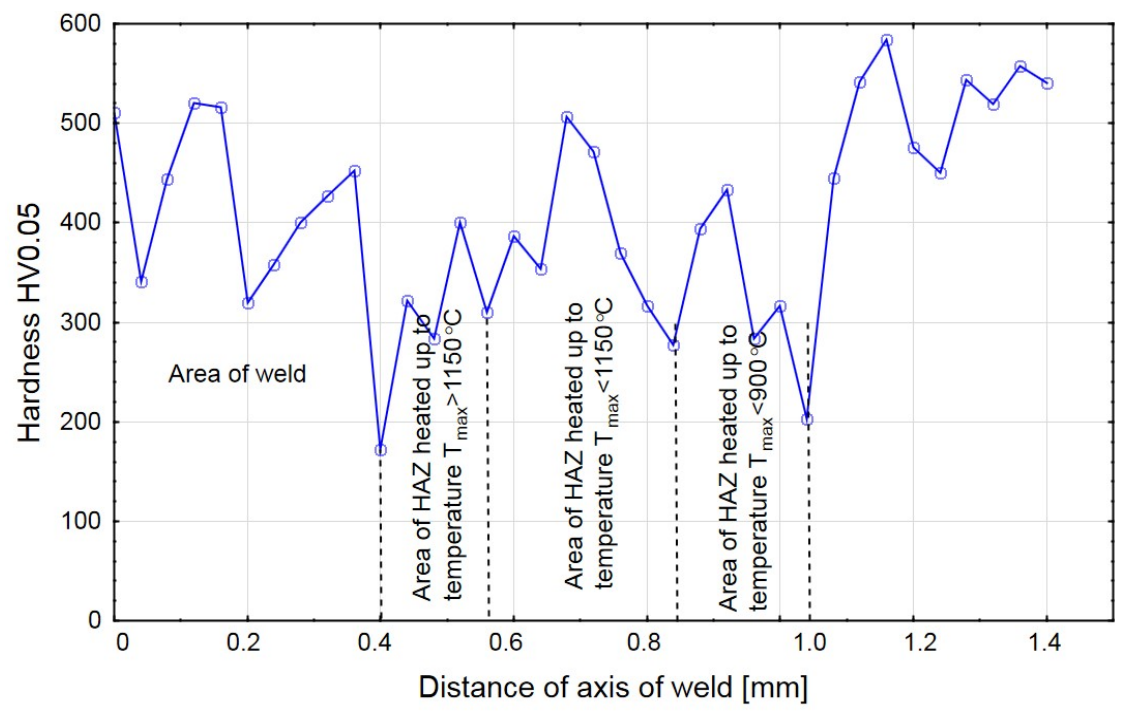

Fig. 7. The hardness profile in the EBW joint of steel Weldox 1300

The microstructures of the individual regions of the electron beam welded joint, Weldox 1300 steel

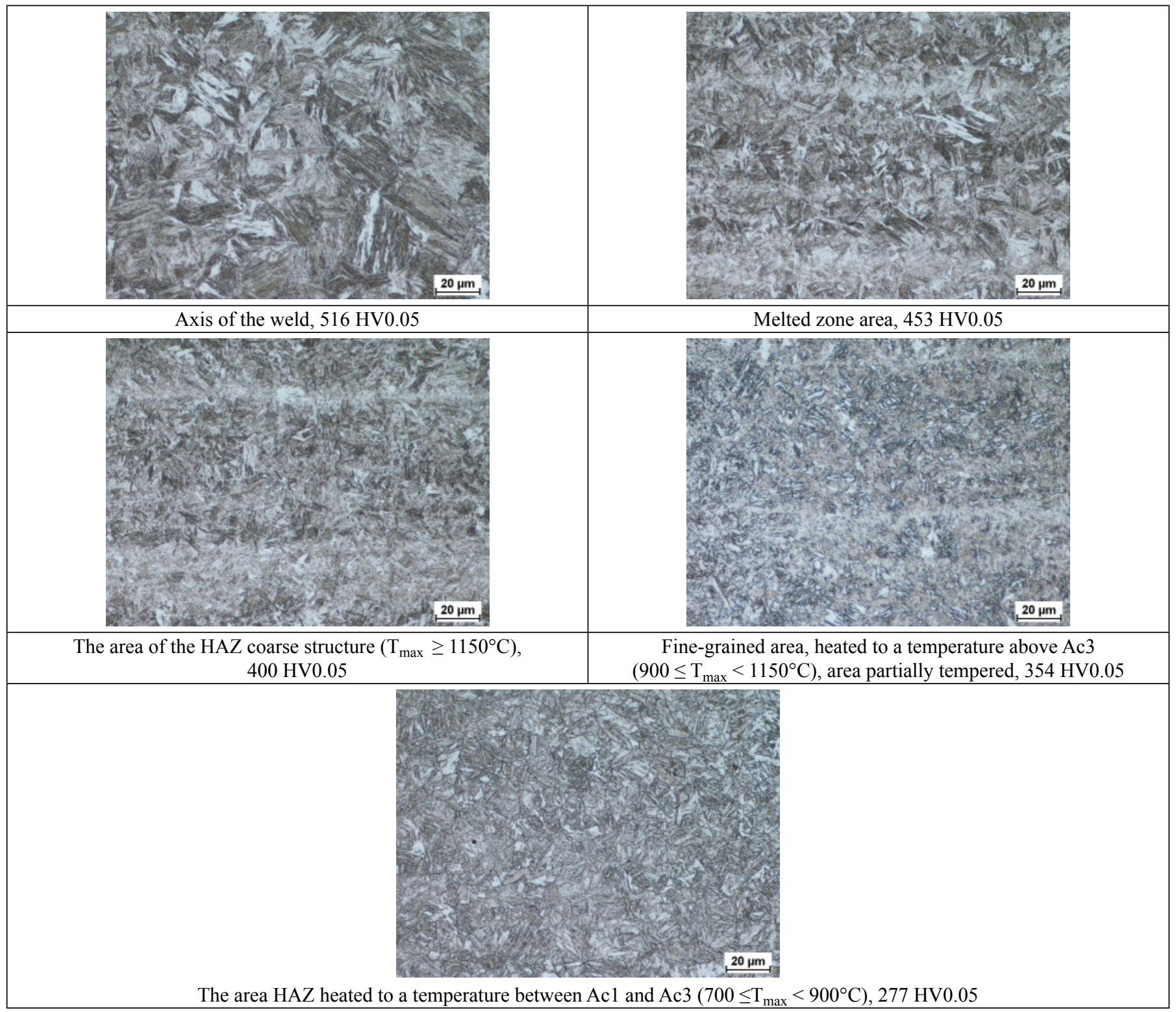


As in the case of S960QL steel joints, the microstructure of the weld Weldox 1300 is not uniform and consists of several zones. The heat affected zone is also not uniform. The results of detail metallography examination of welded joint are given in Table 7.

The mechanical properties of the Weldox 1300 steel joint are presented in Table 8 . The welded joint is characterized by high mechanical properties (TS $=1470 \mathrm{MPa}$ ), however, the plastic properties are not satisfactory. Though the value of impact strength was $45 \mathrm{~J} / \mathrm{cm}^{2}$ (according to manufacturer min $33.7 \mathrm{~J} / \mathrm{cm}^{2}$ ) the required bending angle of $180^{\circ}$ was not achieved. The hardness profile across the EBW joint for the Weldox 1300 steel is shown in Fig. 7. As in the S960QL grade, close to the fusion line (short cooling times $\mathrm{t}_{8 / 5}$ ) the hardness is reduced. Table 9 shows the results of HV10 hardness measurements performed in places depicted in Fig. 1. The hardness decrease up to $172 \mathrm{HV}$ from $322 \mathrm{HV}$ near the fusion line.

TABLE 8

The mechanical properties of the EBW joint of steel Weldox 1300

\begin{tabular}{|c|c|c|c|c|c|}
\hline \multirow{2}{*}{ No. } & \multirow{2}{*}{ Sample designation } & \multicolumn{2}{|c|}{ Strength properties } & \multirow{2}{*}{$\begin{array}{c}\text { Bend angle } \\
{\left[{ }^{\circ}\right]}\end{array}$} & \multirow{2}{*}{ Remarks } \\
\hline & & $F_{m},[k N]$ & $\mathbf{R}_{\mathrm{m}},[\mathrm{MPa}]$ & & \\
\hline 1 & $\mathrm{R} 1$ & 244,7 & 1461 & - & rupture in HAZ \\
\hline 2 & R2 & 246,1 & 1469 & - & rupture in $\mathrm{HAZ}$ \\
\hline 3 & R3 & 248,1 & 1481 & - & rupture in HAZ \\
\hline 4 & FBB1 & - & - & $45^{1}$ & crack in HAZ \\
\hline 5 & FBB2 & - & - & $45^{1}$ & crack in HAZ \\
\hline 6 & RBB1 & - & - & $20^{1}$ & crack in HAZ \\
\hline \multirow[t]{4}{*}{7} & RBB2 & - & - & $20^{1}$ & crack in HAZ \\
\hline & & \multicolumn{3}{|c|}{ Impact strength $[\mathrm{J}] /$ toughness $\left[\mathrm{J} / \mathrm{cm}^{2}\right]$} & \\
\hline & & \multicolumn{3}{|c|}{ Temperature } & \\
\hline & & $0^{\circ} \mathrm{C}$ & $-20^{\circ} \mathrm{C}$ & $-40^{\circ} \mathrm{C}$ & \\
\hline 8 & KV/VW & $38 / 95,0$ & $20 / 50,0$ & $18 / 45,0$ & \\
\hline 9 & $\mathrm{KV} / \mathrm{VW}$ & $30 / 75,0$ & $24 / 60,0$ & $20 / 50,5$ & \\
\hline 10 & KV/VW & - & $24 / 60,0$ & $16 / 40,5$ & \\
\hline \multicolumn{6}{|c|}{ Note: ${ }^{1} 80 \mathrm{~mm}$ diameter of bending mandrel } \\
\hline
\end{tabular}

TABLE 9

The HV10 hardness values for the Weldox 1300 steel EBW joint

\begin{tabular}{|c|c|c|c|c|c|c|c|c|c|c|c|c|c|c|c|}
\hline & 1 & 2 & 3 & 4 & 5 & 6 & 7 & 8 & 9 & 10 & 11 & 12 & 13 & 14 & 15 \\
\hline Linia $A$ & 512 & 512 & 510 & 332 & 336 & 331 & 466 & 468 & 477 & 333 & 336 & 339 & 515 & 518 & 511 \\
\hline Linia B & 512 & 521 & 521 & 343 & 343 & 327 & 478 & 491 & 485 & 345 & 345 & 341 & 518 & 516 & 517 \\
\hline
\end{tabular}

\section{Conclusions}

Based on the metallographic examination and mechanical tests of the electron beam welded joints of steel S960QL and Weldox 1300 the following conclusions can be formulated:

1. Welding of high strength quenched and tempered steels is possible using an high energy electron beam.

2. The fundamental differences in the microstructure between both steels were not observed. The microstructure of the weld area as well as the HAZ was not uniform. Several zones could be distinguished that differ in terms of morphology and the level of hardness.

3. The microstructure of the HAZ depends on the distance from the fusion line and consists of martensite near the fusion line and bainite in the vicinity of the base material.

4. Significant differences in mechanical properties of welded joints for both steel grades were found.

5. In the case of welding S960QL satisfactory mechanical properties were achieved. Though a high strength was achieved in the joint of the Weldox 1300 steel, the required bending angle $\left(180^{\circ}\right)$ was not achieved.

\section{Acknowledgments}

The authors would like to thank The Polish Ministry of Science and Higher Education for financing of research. Research was performed within the framework of the statutory activity of the Instytut Spawalnictwa (Institute of Welding).

\section{REFERENCES}

[1] R. Willms, High strength steel for steel constructions, in: Nordic Steel Construction Conference, Malmo, Sweden, 2009.

[2] M.S. Węglowski, M. Zeman, Prevention of cold cracking in ultra-high strength steel Weldox 1300. Archives of Civil and Mechanical Engineering 14, 417-424 (2014). 
[3] A. Grajcar, Thermodynamic analysis of precipitation processes in $\mathrm{Nb}$-Ti-microalloyed Si-Al TRIP steel, Journal of Thermal Analysis and Calorimetry 118, 1011-1020 (2014).

[4] A. Grajcar, M. Rozanski, S. Stano, et al., Microstructure characterization of laser-welded $\mathrm{Nb}$-microalloyed silicon-aluminum TRIP steel, Journal of Materials Engineering and Performance 23, 3400-3406 (2014).

[5] M.St. Węglowski, K. Krasnowski, K. Kwieciński, R. Jachym, The characteristics of Nd:YAG laser welded joints of dual phase steel, Archives of Civil and Mechanical Engineering 9, 85-97 (2009).

[6] A. Grajcar, M. Rozanski, S. Stano, et al., Effect of heat input on microstructure and hardness distribution of laser welded Si-Al TRIP-type steel, Advances in Materials Science and Engineering, Article Number: 658947 (2014).

[7] T. Wegrzyn, S.Wieszala, Significant alloy elements in welded steel structures of car body, Archives of Metallurgy and Materials 57, 45-52 (2012).

[8] A. Grajcar, W. Zalecki, et al., Dilatometric study of phase transformations in advanced high-strength bainitic steel, Journal of Thermal Analysis and Calorimetry 118, 739-748 (2014).

[9] M.S. Węglowski, S. Stano, G. Michta, W. Osuch, Structural characterization of Nd:YAG laser welded joint of dual phase steel, Archives of Metallurgy and Materials 55, 211-220 (2010).

[10] M.S. Węglowski, M. Zeman, M. Łomozik, Physical Simulation of Weldability of Weldox 1300 Steel, Materials Science Forum 762, 551-555 (2013).

[11] M. Gaspar, A. Balogh, GMAW experiments for advanced (Q+T) high strength steels. Production Processes and Systems 6, No 1, 9-24 (2013).

[12] H. Sumi, K. Oi, K. Yasuda, Effect of chemical composition on microstructure and mechanical properties of laser weld metal of high-tensile-strength steel, Welding in the World 59, 173-178 (2015).

[13] M.S. Weglowski, S. Błacha, A. Phillips, Electron beam welding - Techniques and Trends - Review. Vacuum 130, 72-92 (2016).

[14] V.E. Lazko, Mechanical properties and structure of welded joints in thick high-strength steel produced by electron beam welding and arc welding in a slit-like gap. Welding International 1, 566569 (1987)

[15] G. Zhang, X. Yang, X. He, J. Li, H. Hu, Enhancement of mechanical properties and failure mechanism of electron beam welded
300M ultrahigh strength steel joints. Materials \& Design 45, 56-66 (2013).

[16] S. Elliott, Electron beam welding of C/Mn steels - toughness and fatigue properties. Welding Journal 63, 8-16 (1984).

[17] X. He, X. Yang, G. Zhang, J. Li, H. Hu, Quenching microstructure and properties of $300 \mathrm{M}$ ultra-high strength steel electron beam welded joints. Materials \& Design 40, 386-391 (2012).

[18] S. Schwantes, P. Gerster, K.R. Schulze, Schweißen der höchstfester Feinkornbaustählre S1100QL und S1300QL-Ein Vergleich des Elektronenstrahlschweißen an Atmosphäre mit einem Plasma-MSG-Hybridverfahren. Aachener Berichte Fügetechnik, 543-557 (2007).

[19] Fr.-W. Bach, A. Beniyash, K. Lau, R. Konya, Nonvacuum electron beam welding of structural steels. The Paton Welding Journal, No 5, 22-26 (2009).

[20] T. Hassel, R. Konya, et al., Economical joining of tubular steel towers for wind turbines employing non-vacuum electron beam welding for high-strength steels in comparison with submerged arc welding. Welding in the World 57, 551-559 (2013).

[21] PN-EN 10025-6:2009 Hot rolled products of structural steels Part 6: Technical delivery conditions for flat products of high yield strength structural steels in the quenched and tempered condition.

[22] PN-EN ISO 148-1:2010 Metallic materials - Charpy pendulum impact test - Part 1: Test method.

[23] PN-EN ISO 9016:2013-05 Destructive tests on welds in metallic materials - Impact tests - Test specimen location, notch orientation and examination.

[24] PN-EN ISO 9015-1:2011 Destructive tests on welds in metallic materials - Hardness testing - Part 1: Hardness test on arc welded joints.

[25] PN-EN ISO 6507-1:2007 Metallic materials - Vickers hardness test - Part 1: Test method.

[26] PN-EN ISO 17639:2013-12, Destructive tests on welds in metallic materials - Macroscopic and microscopic examination of welds.

[27] PN-EN ISO 15614-11:2005 Specification and qualification of welding procedures for metallic materials. Welding procedure test. Part 11: Electron and laser beam welding.

[28] P. Seyffarth, R. Schmidt, W.F. Demtschenko, U. Jasnau, Simulation of microstructure - transformation - kinetics of unalloyed constructional steel in case of fast thermal cycles. Proceedings of the 3rd LANE 2001, Meisenbach Verlag, Bamberg, 2001. 